\title{
SISI POSITIF DAN NEGATIF PERSAINGAN ANTARSTASIUN TELEVISI DI INDONESIA DI MATA PENONTON TELEVISI
}

\author{
Rahmat Edi Irawan \\ Jurusan Marketing Communication, Fakultas Ekonomi dan Komunikasi \\ Universitas Bina Nusantara \\ Jln. K.H. Syahdan No. 9, Palmerah, Jakarta Barat 11480
}

\begin{abstract}
Article was aimed to reveal how both positive and negative sides of competition among television stations in Indonesia was seen from their programs seen by television viewers. The study used qualitative methods to get an overview of the phenomena occurring at the social phenomenon. Data were collected by observation and documentary. Observations were made to the programs presented by various television stations, while the documentary was to process data and share ratings released by AGB Nielsen throughout the year 2011. The results show that the competitions between television stations happened today have not presented many positive sides from the viewers because of the limited programs offered in Indonesia. In fact, many programs are aired only a repeatation of the previous successful ones.
\end{abstract}

Keywords: television stations, broadcasted programs, competitive programs, television audience

\begin{abstract}
ABSTRAK
Tujuan penelitian adalah mengungkap sisi positif maupun negatif dari persaingan antarstasiun televisi di Indonesia yang terlihat dari program yang bisa dilihat oleh penonton televisi. Penelitian ini menggunakan metode kualitatif untuk mendapatkan gambaran terhadap fenomena sosial yang terjadi. Pengumpulan data dilakukan dengan observasi dan dokumentasi. Obserbasi dilakukan terhadap program yang disajikan oleh berbagai stasiun televisi, sementara dokumentasi dilakukan dengan mengolah data rating dan share yang dikeluarkan oleh AGB Nielsen sepanjang tahun 2011. Hasil penelitian menunjukkan bahwa persaingan antarstasiun televisi yang terjadi pada saat ini sebenarnya belum banyak menampilkan sisi posistif bagi penonton, karena masih terbatasnya jenis program yang dapat dilihat dari berbagai sajian program yang ditayangkan oleh stasiun televisi di Indonesia. Bahkan, banyak program yang ditayangkan hanya mengulang kesuksesan program lain yang pernah sukses sebelumnya.
\end{abstract}

Kata kunci: stasiun televisi, program siaran, persaingan program, penonton televise 


\section{PENDAHULUAN}

Industri penyiaran di Indonesia berkembang pesat setelah Orde Baru berakhir. Jika sebelum era kekuasaan Soeharto berakhir pada tahun 1998, stasiun televisi baru berjumlah 5 buah untuk swasta nasional dan 1 televisi publik saja, jumlah tersebut sekarang meningkat dua kali lipat menjadi 10 buah untuk swasta nasional dan tetap 1 televis publik, namun masih ditambah dengan ratusan televisi lokal, komunitas dan khusus berlangganan. Kehadiran banyaknya stasiun televisi swasta televisi tersebut tentu saja menyebabkan persaingan antar stasiun televisi, bertambah ketat. Semua stasiun televisi berusaha menyajikan program-program terbaiknya, dengan tujuan ditonton orang sebanyak dan selama mungkin. Bagi stasiun televisi swasta, baik lokal maupun nasional, kehadiran banyaknya penonton, akan memudahkan mereka untuk mendapatkan iklan, yang berarti sumber pemasukan bagi perusahaan tersebut.

Jika dilihat dari perkembangan awal kehadiran televisi memang telah mengubah hidup banyak warga dunia. Televisi bukan lagi sebuah benda mati yang hadir di banyak ruang keluarga, tetapi menjadi media penting dalam proses perkembangan hidup manusia. Sebagai media penyampai pesan, memang televisi menjadi sangat efektif dan efisien dibanding media lainnya. Hal itu disebabkan penggunaan media tersebut menjangkau banyak kalangan di seluruh pelosok dunia, termasuk di Indonesia. Hampir tidak ada wilayah di muka bumi ini yang tidak bisa menangkap siaran televisi, sehingga tidak ada satu daerahpun yang terbebas dari pengaruh televisi. Termasuk di Indonesia, nyaris dari Sabang sampai Merauke terjangkau berbagai siaran televisi yang memenuhi frekuensi udara di Indonesia.

Tidak hanya jangkauan yang luas, televisi juga menjadi media yang paling banyak dikonsumsi penggunaannya dibanding media lainnya. Di Amerika Serikat yang merupakan Negara maju, masyarakatnya menghabiskan waktu 8 jam sehari untuk menonton televisi. Di Indonesia, diperkirakan jumlahnya bisa mencapai lebih dari 10 jam. Waktu mengkonsumsi yang banyak tersebut, tentu saja menyebabkan kehadiran televisi selalu menjadi kajian menarik dalam ilmu komunikasi. Pakar komunikasi, Amerika Serikat, Shirley Biagi dalam bukunya "Media/ Impact" menyatakan televisi adalah media yang telah berhasil mengubah kehidupan sehari-hari manusia atau masyarakat. (Biagi, 2010; 201).

Tentu saja, tingginya konsumsi penggunaan media televisi dalam kehidupan masyaratkan, pada akhirnya menyebabkan banyak pihak ingin terjun ke industri ini, termasuk di Indonesia. Seperti di awal latar belakang, saat ini banyaknya stasiun televisi ini menyebabkan persaingan ketat juga mewarnai bisnis ini. Semua stasiun televisi berusaha untuk menarik penonton sebanyak-banyaknya untuk mau menonton program-program mereka. Fenomena ketatnya persaingan antar stasiun televisi yang menyebabkan pemilik atau pengelola stasiun televisi harus memutar otak untuk mendapatkan penonton sebanyak-banyaknya seharusnya menjadi sebuah sisi yang positif, karena pada akhirnya penontonlah yang akan memilih mana program yang baik dan yang ingin mereka tonton.

Meski demikian, upaya untuk menjaring penonton atau audien yang menjadi faktor terpenting atau segala-galanya bagi stasiun televisi tersebut tidak membuat penonton mendapatkan sisi yang positif dari persaingan antarstasiun televisi tersebut. Jumlah penonton yang banyak cuma dijadikan angka besaran penonton untuk mendapatkan iklan saja. Beberapa program yang tayang di stasiun televisi, banyak yang mengulang program sejenis yang tercatat pernah sukses sebelumnya. Jika hal it uterus terjadi, sebenarnya penonton tidaklah mendapatkan keuntungan dari ketatnya persaingan yang terjadi di industri pertelevisian Indonesia dewasa ini.

Rumusan masalah penelitian ini adalah sebagai berikut, "apa saja sisi positif dan sisi negatif yang terjadi dalam persaingan di industri pertelevisian Indonesia di mata penonton? 


\section{METODE}

Penelitian menggunakan menggunakan metode kualitatif untuk mendapatkan gambaran terhadap fenomena sosial yang terjadi. Pengumpulan data dilakukan dengan observasi dan dokumentasi. Obserbasi dilakukan terhadap program yang disajikan oleh berbagai stasiun televisi, sementara dokumentasi dilakukan dengan mengolah data rating dan share yang dikeluarkan oleh AGB Nielsen sepanjang tahun 2011.

\section{PEMBAHASAN}

Salah satu teori tentang penggunaan atau konsumsi media dikemukakan oleh Elihu Katz, Jay G. Blumler dan Michael Gurevitch yang dikenal sebagai Teori Use and Gratification. Dalam teori tersebut dinyatakan bahwa orang atau penonton akan aktif memilih dan menggunakan media tertentu untuk memuaskan kebutuhan mereka. Karena itu, dalam teori ini, pengaruh media sebenarnya terbatas karena orang atau penonton akan mampu memilih sehingga mampu mengendalikan media. Orang atau penonton dalam teori ini dianggap punya kesadaran diri dan mampu memahami isi media, sehingga dapat menyatakan alasan mereka untuk menggunakan atau memilih media. (West, 2008; 104)

Jika dilihat teori di atas, maka dalam praktek persaingan antarstasiun televisi sekarang adalah penonton akan bebas untuk memilih program acara apa saja atau stasiun televisi mana yang akan mereka tonton setiap saat atau setiap harinya. Mereka bebas memilih dan menikmati tayangan televisi yang mereka suka dan ingin mereka saksikan. Mereka juga bisa saja berpindah dari satu acara ke acara yang lain, dari satu stasiun televisi ke stasiun televisi lainnya, untuk memuaskan kebutuhan mereka. Dengan demikian, maka pemilik atau pengelola stasiun televisi atau televisinya sendiri sebagai sebuah media, pengaruhnya tidak terlalu kuat dalam mendikte keinginan penonton. Artinya, stasiun televisi harus selalu menyajikan acara yang bagus untuk mempertahaknkan penontonnya. Namun, tidak ada kepastian juga penonton akan tetap bertahan menonton program atau stasiun televisi tersebut.

Satu teori lain yang digunakan dalam artikel adalah teori yang dikenal sebagai jarum suntik yang dikemukakan oleh Harold Laswell. Pakar psikologi ini menitikberatkan justru pada demikian kuatnya media dalam mempenharuhi konsumennya. Dengan demikian, apa yang disajikan oleh media, akan diterima atau diikuti begitu saja oleh konsumennya. Kepasifan konsumen disebabkan karena memang mereka tergantung, terbatas atau tidak memiliki kemampuan untuk menolak apa yang disajikan oleh media, sehingga akhirnya tanpa disadari atau terpaksa menjalankan atau melakukan apa yang diinginkan oleh media tersebut. (Vivian, 2008; 469-470)

Kedua teori di atas dapat dilihat dalam praktik industri pertelevissian Indonesia saat ini. Saat ini, penonton punya kebebasan stasiun televisi mana yang akan mereka pilih untuk mereka tonton, sehingga terasa tidak ada pemaksaan penonton untuk memilih program acara yang mereka suka. Kondisi seperti itu, tentu cocok dengan teori pertama yang digunakan, yaitu teori Uses and Gratification. Sementara, permasalahannya, akibat adanya persamaan jenis program yang disajikan beberapa stasiun televisi, adanya program yang hanya sekedar mengikuti atau menjiplak program yang sudah sukses sebelumnya, adanya program yang talent atau pengisi acaranya yang itu-itu saja, barangkali bentuk baru dari masih adanya kekuasaan stasiun televisi untuk memaksakan tontonan mereka untuk dipilih atau tetap ditonton oleh penonton televisi. Sebuah kondisi yang cocok dengan penggunaan teori kedua yang dikemukakan Harold Laswell, tentang kuatnya media mempenharuhi penggunya. Kedua teori tersebut akan digunakan dalam bahasan artikel. 


\section{Perkembangan Industri Pertelevisian di Indonesia}

Meski siaran perdana televisi di Indonesia sudah dimulai pada tahun 1962, kenyataannya Indonesia memasuki era industri pertelevisian dalam dua dekade terakhir saja. Selama lebih dari 30 tahun, rakyat Indonesia hanya disuguhi tontonan televisi yang ditayangkan oleh Televisi Republik Indonesia (TVRI) sebagai televisi milik pemerintah, yang merupakan stasiun televisi pertama dan satu-satunya yang boleh mengudara pada masa kekuasaan Orde Baru. Industri pertelevisian di Indonesia baru menggeliat pada akhir kekuasaan Soeharto, ketika pihak swasta diperbolehkan untuk melakukan siaran televisi. Satu per satu, televisi mengudara, dimulai dengan Rajawali Citra Televisi Indonesia (RCTI) yang melakukan siaran pertama pada tahun 1989. Lalu berturut-turut diikuti oleh Surya Citra Televisi (SCTV), Televisi Pendidikan Indonesia (TPI), Cakrawala Andalas Televisi (ANTV) dan Indosiar Visual Mandiri (Indosiar) yang memulai siaran sebelum pemerintahan Presiden Suharo berakhir.

Memasuki era reformasi, kian banyak stasiun televisi swasta bermunculan. Tercatat lima televisi swasta nasional memulai siaran, yaitu Metro TV, Global TV, Trans TV, TV7 (sekarang Trans7) dan Lativi (sekarang TV One). Jumlah itu masih ditambah dengan munculnya stasiun televisi swasta lokal yang juga ikut meramaikan frekuensi siaran televisi di Indonesia. Maraknya pertumbuhan televisi swasta tersebut tentu tidak bisa dilepaskan dari dari aspek ekonomis dan politis yang menjadi magnet bagi industri pertelevisian. Aspek ekonomis misalnya, dilihat dari belanja iklan yang dibelanjakan ke televisi selama tahun 2011 mencapai jumlah lebih dari 10 trliun rupiah. Jumlah tersebut meningkat sebanyak 2 triliun rupiah atau sebesar $20 \%$ dari jumlah tahun lalu. Jumlah tersebut juga sama dengan 65. \% dari total belanja iklan sepanjang tahun lalu. Meski banyak disedot hanya beberapa stasiun televisi swasta nasional saja, jumlah yang sedemikian besar tersebut tentu menjadi incaran mereka yang punya uang banyak dan ingin berinvestasi dalam bisnis ini.

Namun, di luar pertimbangan ekonomis aspek politis memiliki stasiun televisi juga menjadi pertimbangan banyaknya pemilik modal mau terjun di industri pertelevisian. Fungsi media yang salah satunya sebagai sumber informasi menjadi alasan kuat kenapa banyak pemilik modal atau penguasa yang rela mengeluarkan uang banyak untuk memiliki stasiun televisi. Dengan memiliki stasiun televisi dianggap sebagai media yang paling efektif untuk memberikan informasi dan mempengaruhi penonton dengan berbagai ide atau gagasan yang dimilikinya kepada masyarakat. Hal tersebut juga ditunjang dengan kenyataan, saat ini tercatat sebanyak ... pesawat televisi yang ada di semua rumah tangga di Indonesia. Sebuah jumlah yang paling banyak sebagai media yang dikonsumsi masyarakat tanah air. Belum lagi, saat ini setidaknya setiap hari tercatat 10-12 jam orang Indonesia menonton televisi. Dengan demikian, wajar jika televisi menjadi media yang paling efektif untuk berkampanye, termasuk untuk kepentingan politis.

Dengan dua dasar pertimbangan di atas, rasanya industri pertelevisian di Indonesia, masih akan menarik banyak pemain baru untuk terjun di bisnis ini. Memang harus diakui, pada era sekarang ini, agak sulit untuk mendapatkan izin siaran televisi teresterial baru di beberapa kota besar di Indonesia. Hal tersebut terjadi karena keterbatasan frekuensi siaran yang ada menyebabkan tidak mungkin lagi ada siaran televisi yang dipancarkan melalui gelombang elektro magnetik tersebut. Namun hal tersebut nantinya diperkirakan sudah tidak menjadi masalah lagi, dengan dimulainya era televisi digital di Indonesia. Dengan teknologi digital, maka frekuensi siaran akan sanggup menampung hampir 10 kali lipat jumlah stasiun televisi yang kini bersiaran di Indonesia. Artinya, sejumlah investor yang selama ini kesulitan mendapatkan izin siaran televisi untuk membuka stasiun televisi, nantinya akan memiliki izin siaran televisi baru yang akan meramaikan bisnis pertelevisian di Indonesia. Dengan demikian, pada masa yang akan dating, akan semakin banyak pula stasiun televisi swasta yang akan tayang di Indonesia. (Mufid, 2007, hal; 55-57). 


\section{Persaingan Program Televisi}

Kian banyaknya jumlah stasiun televisi yang melakukan siaran di Indonesia, secara pasti akan berdampak pula dengan kian ketatnya persaingan antar stasiun televisi swasta tersebut. Semua stasiun televisi swasta tersebut tentu akan berupaya untuk menarik penonton sebanyak-banyaknya dan selama mungkin menjadi penonton mereka, Jumlah penonton yang banyak dan lama yang dimiliki oleh sebuah stasiun televisi, tentu akan memudahkan mereka untuk mendapatkan iklan. Saat ini, kebanyakan pemasang iklan di televisi tentu akan mempertimbangkan seberapa banyak dan seberapa lama penonton yang menyaksikan sebuah tayangan, untuk memasang iklan-iklan mereka. Bahkan, harga satu penayangan iklan pada suatu waktu di sebuah stasiun televisi tertentu, besarannya juga melihat banyak dan lamanya jumlah penonton di waktu tersebut. Sementara kita juga tahu, bahwa masalah iklan adalah persoalan hidup mati bagi stasiun televisi. Dengan banyaknya iklan biasanya semakin banyak pula uang yang masuk untuk stasiun televisi tersebut.

Bagi sebuah stasiun televisi upaya untuk menarik jumlah penonton sebanyak-banyak dan selama mungkin, dilakukan dengan jalan menayangkan program terbaik yang mereka miliki, baik yang mereka beli (program akuisisi) atau program yang mereka buat sendiri (in house production). Dengan demikian, program televisi dapat dikatakan sebagai senjata bagi stasiun televisi untuk menjaring penonton, sehingga didapat pula pemasang iklan yang akan memberikan pemasukan uang bagi mereka. Untuk itu, program yang ditayangkan sebuah stasiun televisi dapat dikatakan baik, bagus atau berhasil jika program tersebut mampu menarik penonton sebanyak dan selama mungkin menyaksikan tayangan tersebut. Kesediaan penonton menyaksikan sebuah tayangan atau program sebanyak dan selama mungkin itulah yang dalam industri pertelevisian disebut dengan rating. Istilah rating mengacu pada jumlah penonton yang menyaksikan sebuah tayangan atau program di sebuah stasiun televisi. Selain rating, industri pertelevisian juga mengenal share untuk mengukur keberhasilan sebuah program televisi. Khusus untuk share mengacu pada prosentase yang didapat sebuah program dibanding dengan total jumlah penonton lain yang menonton televisi di waktu tersebut. Saat ini, rating dan share yang dipercaya semua stasiun televisi dan pemasang iklan adalah yang dikeluarkan oleh AGB Nielsen. (AGB Nielsen sepanjang 2011)

Meski kerap banyak mendapat kritikan, namun rating dan share yang dikeluarkan oleh AGB Nielsen tersebut saat ini menjadi satu-satunya rujukan data kuantatif untuk menentukan keberhasilan sebuah program merebut penonton televisi. Barangkali, karena dipercaya oleh pemasang iklan, maka rating dan share versi AGB Nielsen yang bersumber dari penonton di 10 kota besar Indonesia, masih menjadi acuan para praktisi industri pertelevisian di Indonesia. Masalah yang kerap ditundingkan pada data kuantitatif yang dikleuarkan AGB Nielsen ini hanya memotret sebuah program berdasarkan keberhasilan menjaring penonton sebanyak dan selama mungkin, padahal kalau dilihat sebuah program televisi yang sukses ditonton oleh banyak orang, terkadang juga bukan program televisi yang bagus, baik secara isi program maupun pengemasan programnya. Masih terdapat program yang ditonton banyak orang, tetapi justru isi atau pesan yang disampaikan dalam program tersebut amat berbahaya bagi sebagian penonton televisi. Atau, masih ada juga program televisi yang penontonnya banyak, tetapi pengemasan program, baik dari segi gambar maupun suara yang terkesan apa adanya, kalau tidak dikatakan jelek.Memadukan antara kepentingan mendapatkan rating dan share yang tinggi, tanpa meninggalkan kualitas program yang bagus, tentu menjadi tantangan bagi setiap praktisi penyiaran di Indonesia saat ini.

Keharusan untuk menayangkan program yang punya rating dan share tinggi serta berkualitas baik secara isi maupun pengemasannya, masih belum cukup. Stasiun televisi maupun para praktisi pertelevisian juga diminta untuk tidak melanggar aturan main atau rambu-rambu dalam regulasi penyiaran di Indonesia. Sejak 10 tahun terakhir, Komisi Penyiaran Indonesia (KPI) yang mengawasi semua tayangan televisi sudah melahirkan produk Pedoman Perilaku Penyiaran dan Standar Program Siaran (P3SPS) untuk mengatur mana yang boleh dan tidak boleh ada dalam sebuah program televisi 
di Indonesia. Selain itu, dalam regulasi tersebut juga diatur tentang sanksi atau hukuman yang akan diterima lembaga penyiaran atau praktisi penyiaran yang melakukan pelanggaran terhadap ramburambu tersebut. Dengan keharusan menghormati regulasi penyiaran tadi, sebenarnya semakin tidak mudah bagi lembaga dan praktisi penyiaran dalam menghadapi persaingan antar stasiun televisi swasta. Secara keseluruhan, sebuah program haruslah ditonton banyak orang, dengan tetap menjaga kualitas produk programnya tersebut, dan juga tanpa melanggar aturan main dalam regulasi penyiaran di Indonesia.

\section{Sisi Positif dan Sisi Negatif Persaingan}

Lalu, pertanyaannya sekarang, apa saja sisi poistif dan sisi negatif dari persaingan antar stasiun televisi, dengan berbagai program yang sudah dibuat atau dibeli oleh stasiun televisi tersebut, bagi penonton televisi di Indonesia? Sebelum menjawab pertanyaan tersebut, ada baiknya kita membuka dulu data-data yang dikeluarkan oleh AGB Nielsen sepanjang tahun 2011 lalu.

Sepanjang tahun 2011 lalu, tercatat lebih dari 500 judul program ditayangkan oleh 10 stasiun televisi swasta nasional di Indonesia. Jumlah tersebut tentu tidak sedikit, dan akan jauh lebih banyak lagi kalau kita melihat bahwa setiap judul program pasti ada yang ditayangkan secara stripping setiap hari dengan durasi yang bervariasi, dari 30 menit hingga lebih 2 jam lebih. Dari judul program tersebut, kalau dikelompokkan secara genre atau jenis program, maka akan terlihat dikuasai oleh 3 genre program saja, yaitu drama, berita dan sports match. Jika dilihat dari keberhasilan sebuah program merebut penonton terbanyak berdasarkan data yang dikeluarkan AGB Nielsen tersebut maka hanya 5 genre program saja yang pernah menjadi program terbanyak penontonnya dalam waktu seminggu, yaitu series tercatat 25 minggu, sports match tercatat 15 minggu, comedy 9 minggu, special event 3 minggu dan filler news 2 minggu. (Data AGB Nielsen sepanjang 2011)

Jika dilihat dari data di atas, secara kuantitas, jumlah judul program yang ditayangkan disemua stasiun televisi memang cukup banyak. Dengan melihat data di tersebut, barangkali penonton televisi di Indonesia memang cukup beruntung atau mendapatkan berkah bahwa persaingan antar stasiun televisi membuat mereka punya kesempatan untuk menyaksikan banyak judul tayangan televisi. Berbagai program tayangan televisi memang sudah dijajakan oleh stasiun televisi untuk merebut hati penonton sebanyak-banyaknya. Artinya, selama setahun ini penonton televisi sudah dimanjakan untuk memilih banyak judul program yang mereka sukai untuk menjadi pilihan tontonan mereka. Banyaknya judul program juga menjadi pertanda bahwa jika ada program atau tayangan televisi yang tidak disukai oleh penonton, maka akan segera diganti oleh tayangan lain. Jika ini menjadi patokan, maka sudah pasti hal tersebut menjadi sebuah sisi positif bagi penonton, karena mereka menjadi raja atas kelayakan kelangsungan sebuah tayangan.

Namun, jika dikaji secara lebih mendalam lagi atas data yang dikeluarkan oleh AGB Nielsen dalam setahun terakhir, sebenarnya penonton televisi di Indonesia tidaklah terlalu mendapat sisi positif dari persaingan antar program televisi yang terjadi saat ini. Dengan hanya terpaku pada beberapa jenis program saja yang ditayangkan, bisa disimpulkan bahwa pihak stasiun televisi atau praktisi pertelevisian di Indonesia belum menunjukkan kreativitas yang maksimal dalam berkarya. Artinya, banyak program yang hanya meniru atau sekilas terlihat sama dengan program dengan jenis yang sama yang sudah meraih sukses sebelumnya. Mereka hanya bermain aman dengan menciptakan program yang secara kreatif sebenarnya hanya meniru program yang telah sukses sebelumnya.

Hal tersebut semakin diperkuat dengan hanya sedikitnya jenis program yang berhasil menjadi top program atau program yang terbanyak penontonnya selama satu minggu. Artinya, selain program itu saja yang menempati top program dalam Data AGB Nielsen, para pembuat program distasiun televisi sebenarnya hanya membuat program duplikasi dari program sebelumnya yang terbukti sukses merebut penonton sebanyak mungkin. Tidak banyak jenis program lain yang diberikan kepada 
penonton, sehingga sebenarnya penonton tidak terlalu banyak pilihan atas genre program yang bisa mereka pilih. Penonton kembali didikte stasiun televisi yang sudah memilih jenis program yang itu-itu saja, yang ditayangkan oleh stasiun-stasiun televisi tersebut.

Kebanyakan stasiun televisi pada akhirnya memang tidak berani melakukan inovasi terhadap program yang mereka tayangkan. Keharusan membuat program yang harus ditonton sebanyak mungkin penonton hingga bisa mendapatkan iklan yang banyak hanya diartikan sempit, yaitu hanya menayangkan program yang sesuai dengan selera pasar saja. Tidak ada upaya untuk ke luar dari main stream jenis program, sehingga tidak banyak lahir program yang unik atau beda antar satu stasiun televisi dengan stasiun televisi lain. Bahkan, lebih parahnya, pengisi acara atau talent yang ditampilkan semua stasiun televisi hampir seragam, yaitu mereka yang kebetulan sedang popular pada saat itu. Sementara keharusan membuat program yang berkualitas bagus baik secara isi maupun pengemasan, diartikan hanya sebagai program yang enak untuk dilihat dan ditonton saja. Mereka tidak lagi peduli bahwa program itu hanya pengulangan dari program yang dulu pernah dibuat dan sukses ditonton banyak orang.

Keharusan membuat program untuk tidak melanggar aturan main dalam regulasi penyiaran juga akhirnya hanya menjadi belenggu kreativitas stasiun televisi dan praktisi penyiaran untuk bermain lebih aman lagi, tanpa perlu memikirkan suatu tontonan yang bisa memberikan nilai lebih bagi penontonnya. Dengan alasan ketakutan pada regulasi penyiaran, program yang dihasilkan ibaran sayur tanpa garam, yang tidak punya nyawa kreativitas. Jika semua itu yang terjadi, rasanya persaingan antarprogram televisi bukan hanya sekedar memberi sisi positif bagi penonton, tetapi justru lebih banyak menampilkan sisi negatif bagi penonton yang menyaksikan.

\section{SIMPULAN}

Babak baru pertelevisian di Indonesia, yang ditandai dengan diberikannya izin dan frekuensi siaran televisi swasta di Indonesia, pada akhirnya melahirkan persaingan antarstasiun televisi yang melakukan siaran di Indonesia. Persaingan antarstasiun televisi tersebut ditandai dengan persaingan antarprogram atau acara televisi. Melalui program acara tersebut, stasiun televisi berusaha untuk menarik sebanyak dan selama mungkin menonton acara atau stasiun televisi mereka. Keberhasilan merebut penonton sebanyak dan selama mungkin akan memudahkan stasiun televisi tersebut untuk mendapatkan iklan, yang menjadi sumber pemasukan utama dari banyak stasiun televisi swasta.

Meski masing-masing stasiun televisi berusaha untuk menyajikan program acara terbaik mereka, bukan berarti penonton dapat dikatakan mendapatkan sisi positif dari adanya persaingan antar stasiun televisi tersebut. Jika dilihat dari jumlah episode maupun jumlah judul program yang ditayangkan selama tahun 2011 lalu, memang terlihat terjadinya peningkatan secara kuantitas. Namun penambahan jumlah tersebut tidak dibarengi dengan keragaman jenis program, keragaman isi atau kreatifitas program maupun keragaman talent atau pengisi acara dari semua program-program yang ditayangkan, yang akhirnya membuat penonton lebih banyak mendapatkan sisi negatif dari persaingan yang terjadi antar stasiun televisi tersebut. Tidak banyak keragaman jenis program, ini terlihat dari hanya jenis program drama dan pertandingan olahraga misalnya, masih menjadi tayangan yang dominan. Bukti lain dari tidak adanya keragaman jenis program terlihat dari hanya beberapa jenis program saja yang berhasil menjaring penonton terbanyak. Sementara untuk tidak banyaknya keragaman isi, bisa dilihat mulai banyaknya program-program yang sekedar mencontek ide program sukses sebelumnya. Sementara untuk tidak banyaknya keragaman talent, bisa terlihat dari banyaknya talent yang selalu ada di banyak program acara di berbagai stasiun televisi. 


\section{DAFTAR PUSTAKA}

Morissan, Andi Corry Wardhani, Farid Umar. (2010). Teori Komunikasi Massa. Jakarta: Ghalia Indonesia.

Muhamad Mufid. (2007). Komunikasi \& Regulasi Penyiaran. Jakarta: Kencana.

Shierly,B. (2010). Media Impact. Jakarta; Penerbit Salemba Humanika.

Vivian, J. (2008). Teori Komunikas. Jakarta : Kencana.

West, R., \& Lynn h. Turner. (2008). Teori Pengantar Komunikasi. Jakarta : Penerbit Salemba. 